\title{
Research of Hydrogen Production by Dimethyl Ether Reforming in Fuel Cells
}

\author{
Lei Guo \\ College of Automotive Engineering, Shanghai University of Engineering Science, Shanghai, China \\ Email: 594692549@qq.com
}

How to cite this paper: Guo, L. (2018) Research of Hydrogen Production by Dimethyl Ether Reforming in Fuel Cells. Open Access Library Journal, 5: e4266. https://doi.org/10.4236/oalib.1104266

Received: December 18, 2017

Accepted: January 16, 2018

Published: January 19, 2018

Copyright (๑) 2018 by author and Open Access Library Inc.

This work is licensed under the Creative Commons Attribution International License (CC BY 4.0).

http://creativecommons.org/licenses/by/4.0/

\begin{abstract}
Dimethyl ether is a kind of clean fuel, which is expected to replace traditional fuel to achieve high efficiency and low emission. The research of hydrogen production by vehicle dimethyl ether reforming is imminent. This article summarizes and comments the progress of hydrogen production by dimethyl ether reforming, briefly analyzing new method of preparing catalyst. Three existing methods for hydrogen from dimethyl ether, namely steam reforming, autothermal reforming and partial oxidation reforming, are introduced. In this paper, recent researches in the field of hydrogen from dimethyl ether are reviewed.
\end{abstract}

\section{Subject Areas}

Computational Chemistry

\section{Keywords}

Dimethyl Ether, Fuel Cells, Reforming, Catalyst

\section{Introduction}

With the rapid development of economy, the demand for oil resources is increasing day by day, and the import of a large amount of oil will affect the energy security. Therefore, the development of alternative fuels and the development of clean energy have become an important choice of energy strategy. In recent years, dimethyl ether has become a hot topic of petroleum substitution products and new two energy sources, which has aroused great concern and attention of governments and experts in Europe, America, and Japan. The development of the dimethyl ether economic system is of great strategic significance for economic development, environmental protection and ecological balance [1] [2]. 
The generation of hydrogen from fossil fuels such as alcohols, ethers and hydrocarbons for fuel cell power generation is considered to be one of the most realistic hydrogen source solutions in the near and medium term. However, these substances have some defects in the process of reforming hydrogen production, such as, hydrogen production by methane reforming requires a higher temperature, while additional hydrogen gasification equipment is needed during the process of reforming methanol to hydrogen, which increases the operation cost, and methanol has certain toxicity [3]. When a small amount of hydrogen is added to the dimethyl ether engine, the advantages are as follows: 1) high combustion efficiency; 2) reduce emissions of $\mathrm{NO}_{\mathrm{x}}$ and soot in automobile exhaust [4] [5]. DME is an environmentally friendly clean and safe liquid fuel. It is easy to compress into liquid, and DME has the advantages of high energy density, non-toxicity, easy availability, safe handling and storage [6] [7] [8].

\section{Method and Mechanism of Hydrogen Production from DME}

\subsection{Method of Hydrogen Production from DME}

Two ways of hydrogen production by reforming of dimethyl ether are as follows: DME steam reforming (DME SR), DME partial oxidation reforming of hydrogen (POX), DME autothermal reforming (DME ATR), and technology of DME plasma [9].

Steam reforming of DME process involves following four main reactions [10]:

1) Water-gas shift:

$$
\mathrm{CO}_{2}+\mathrm{H}_{2}=\mathrm{CO}+\mathrm{H}_{2} \mathrm{O}(\mathrm{g}) \quad \Delta \mathrm{H}_{298}=41.2 \mathrm{~kJ} / \mathrm{mol}
$$

2) DME hydrolysis:

$$
\mathrm{CH}_{3} \mathrm{OCH}_{3}+\mathrm{H}_{2} \mathrm{O}(\mathrm{g})=2 \mathrm{CH}_{3} \mathrm{OH} \quad \Delta \mathrm{H}_{298}=37 \mathrm{~kJ} / \mathrm{mol}
$$

3) Steam reforming of methanol:

$$
\mathrm{CH}_{3} \mathrm{OH}+\mathrm{H}_{2} \mathrm{O}=3 \mathrm{H}_{2}+\mathrm{CO}_{2} \quad \Delta \mathrm{H}_{298}=49 \mathrm{~kJ} / \mathrm{mol}
$$

4) Methanol decomposition:

$$
\mathrm{CH}_{3} \mathrm{OH}(\mathrm{g})=2 \mathrm{H}_{2}+\mathrm{CO} \quad \Delta \mathrm{H}_{298}=91 \mathrm{~kJ} / \mathrm{mol}
$$

SR has been widely used in different industrial production of hydrogen, however, the reaction is endothermic, this process requires high external heat source. Francis A. Elewuwa et al. presents a computational parametric analysis of DME steam reforming in a large scale Circulating Fluidized Bed (CFB) reactor [11] [12]. Feng et al. has presented a kinetic rate of total combustion of DME based on copper-based catalyst [13].

Partial oxidation of DME reaction:

$$
\mathrm{CH}_{3} \mathrm{OCH}_{3}+1 / 2 \mathrm{O}_{2}=2 \mathrm{CO}+3 \mathrm{H}_{2} \quad \Delta \mathrm{H}_{298}=38 \mathrm{~kJ} / \mathrm{mol}
$$

Partial oxidation process is an exothermic process with quick start and less complex, however, high carbon monoxide concentration produced in the reaction 
will poison the catalyst of the fuel cell.

Autothermal reforming of DME reaction:

$$
\begin{array}{ll}
\mathrm{CH}_{3} \mathrm{OCH}_{3}+0.5 \mathrm{O}_{2}(\mathrm{~g})=3 \mathrm{H}_{2}+2 \mathrm{CO}_{2} & \Delta \mathrm{H}_{298}=-38 \mathrm{~kJ} / \mathrm{mol} \\
\mathrm{CH}_{3} \mathrm{OCH}_{3}+\mathrm{H}_{2} \mathrm{O}(\mathrm{g})=6 \mathrm{H}_{2}+2 \mathrm{CO}_{2} & \Delta \mathrm{H}_{298}=135 \mathrm{~kJ} / \mathrm{mol}
\end{array}
$$

The autothermal reforming of dimethyl ether is the coupling of the two reforming methods. By this method, the concentration of hydrogen in high concentration products is avoided, and no external heating is needed. The purpose of this research is to supply hydrogen for large fuel cell vehicle. Derek Creaser et al. developed a global kinetic model for the autothermal reforming of dimethyl ether (DME) over a $\mathrm{Pd}-\mathrm{Zn} / \mathrm{Al}_{2} \mathrm{O}_{3}$ catalyst on a cordierite monolith [14]. M. H. Akbari et al. presented a numerical investigation of catalytic autothermal reforming of methane in a surface microreactor [15].

The principle of plasma hydrogen production is radical plasma rich mixture using hydrocarbon fuel and air by arc discharge generated in the region, caused by partial oxidation reaction to produce hydrogen rich gas, hydrogen is considered a high efficiency and low cost. The method is similar to the traditional method of hydrogen production, the difference is that the active substances that excite the chemical reactions are different.

\subsection{Mechanism of Hydrogen Production from DME}

Hydrogen production from steam reforming of DEM is a continuous reaction: the first step is DME hydrolysis into methanol on an acidic catalyst; the second step is to produce hydrogen in the methanol reforming of the metal catalyst. The DME hydration of methanol is a thermodynamic equilibrium limit, but immediately produced methanol steam reforming reaction. In addition to the above 2 reactions, water gas shift reaction (WGSR) may occur [16] [17].

The mechanism of hydrogen production by DME steam reforming should be based on the mechanism of two methyl ether hydration and methanol steam reforming, and the mechanism of DME synthesis, methanol dehydration and water gas shift reaction should be combined. Study on the DME steam reforming mechanism and kinetics of hydrogen production, establish reasonable rate model, the DME conversion and hydrogen yield forecast, provide for the design of the reformer dynamic information and dynamic data needed is very important, which can accelerate the fuel cell vehicle commercialization process.

Kinetic modeling of catalytic steam reforming of DME is as following:

1) DME hydrolysis into methanol [13]

$$
r_{\mathrm{DME}}=r_{\mathrm{DMO}^{+}}=k_{F, \mathrm{DMO}^{+}}^{\prime} C_{R_{1}^{+}}-k_{C, \mathrm{DMO}^{+}}^{\prime} C_{\mathrm{DMO}^{+}}
$$

2) Methanol steam reforming [18]

$$
r_{R}=(1-\varepsilon) \rho_{s} k_{R} C_{\mathrm{CH}_{3} \mathrm{OH}}
$$

3) Methanol decomposition [18]

$$
r_{D}=(1-\varepsilon) \rho_{s} k_{D}
$$


4) WGS reaction [19]

$$
r_{\mathrm{WGS}}=C_{\mathrm{WGS}} k_{\mathrm{WGS}}\left(p_{\mathrm{CO}} p_{\mathrm{H}_{2} \mathrm{O}}-p_{\mathrm{CO}} p_{\mathrm{H}_{2}} / K_{e q}\right)
$$

\subsection{Influence of Operating Parameters}

The main factors affecting the reaction rate and chemical balance of hydrogen production by steam reforming of two methyl ether are as follows:

1) Temperature. Because the reaction of hydrogen production by steam reforming of DME is endothermic, the conversion rate increases with the increase of temperature, but the concentration of $\mathrm{CO}$ increases. Therefore, in order to save energy and reduce the content of $\mathrm{CO}$ in the products, a low reaction temperature should be adopted to match the fuel cell.

2) Pressure. As the reaction is an increase in volume, the conversion decreases as the pressure increases. If the membrane reactor is adopted, the reaction system should have a certain pressure. Feed ratio of water and DME. With the increase of water quantity, the conversion of DME can be promoted.

\section{Catalyst for Reforming of DME}

There are very strict restrictions on the content of hydrogen rich gas supplied in CO PEMFC, and electric vehicles for fuel cell power supply requirements of compact structure and small device, so to ensure the high hydrogen yield at the same time, should reduce the content of $\mathrm{CO}$ in hydrogen rich gas. Therefore, the search for catalysts with low temperature, high activity and high selectivity is the focus of the study on the two methyl ether reforming, and also a key technology for hydrogen production on board.

\subsection{Catalyst for Steam Reforming of DME}

DME steam reforming catalyst active component generally consists of two parts: solid acid catalyst and metal or metal oxide, wherein the solid acid catalyst to help DME hydrolysis reaction, and metal or metal oxide contributes to the methanol reforming reaction. The study shows that the hydrolysis rate of DME is the speed control step of the whole reforming process. Therefore, scholars at home and abroad have done a lot of research on the effect of acid carrier in the process of hydrolysis of DME. According to the micro reversibility principle of chemical reaction, a solid acid catalyst with good activity in the process of methanol dehydration to produce DME is proposed. Feng et al. [13] developed a one-dimensional isotherm plug flow model to simulate DME-SR in a fixed bed reactor with bifunctional catalyst $\mathrm{CuO} / \mathrm{ZnO} / \mathrm{Al}_{2} \mathrm{O}_{3} /+\mathrm{ZSM}-5$. Other catalysts, such as mechanically mixed $\mathrm{HPA} / \mathrm{Al}_{2} \mathrm{O}_{3}$ acidic catalyst and $\mathrm{Cu} / \mathrm{SiO}_{2}$ metallic catalyst, have been tested experimentally in a fixed bed reactor and reported to achieve near $100 \%$ DME conversion at $290^{\circ} \mathrm{C}[20]$.

\subsection{Catalyst for Autothermal Reforming of DME}

Autothermal reforming of DME is the coupling of the two DME hydrogen 
production methods, and has the advantages of two reactions, namely, steam reforming and partial oxidation. Derek Creaser 8 et al. proposed a global kinetic model for the autothermal reforming of dimethyl ether (DME) over a $\mathrm{Pd}-\mathrm{Zn} / \mathrm{Al}_{2} \mathrm{O}_{3}$ catalyst [14]. M. Nilsson [21] et al. has tested the performance of the catalysts in a small-scale reactor, using cordierite monoliths as substrate. The catalysts exhibited high activity and generated hydrogen-rich product gases with $\mathrm{CO}$ concentrations below 5 vol.\% in the temperature range between $350^{\circ} \mathrm{C}$ and $450^{\circ} \mathrm{C}\left(\right.$ at $\mathrm{O}_{2}: \mathrm{DME}=0.7, \mathrm{H}_{2} \mathrm{O}: \mathrm{DME}=2.5$, and GHSV $\left.=15,000 \mathrm{~h}^{-1}\right)$.

\subsection{Catalyst for Partial Oxidation Reforming of DME}

Hydrogen production by partial oxidation reforming of two - methyl ether is an exothermic reaction, and it is easy to form a "hot spot" in the reactor, resulting in the decrease of the effective utilization coefficient of the catalyst. Zhang [22] et al. has proposed that $\mathrm{H}_{2}$ yield of more than $90 \%$ was obtained with little methane production over $\mathrm{Pt} / \mathrm{Al}_{2} \mathrm{O}_{3}$ and $\mathrm{Ni}-\mathrm{MgO}$ combined catalysts. $\mathrm{Ni}-\mathrm{MgO}$ was active for the reforming of DME as well as for the reforming of $\mathrm{CH}_{4}$, which formed through a homogeneous reaction between DME and oxygen. Chen [23] et al. presents results of DME partial oxidation over a $1.5 \mathrm{wt} \% \mathrm{Pt} / \mathrm{Ce}_{0.4} \mathrm{Zr}_{0.6} \mathrm{O}_{2}$ catalyst under the condition of gas hourly space velocity (GHSV) of 15,000 $60,000 \mathrm{ml} /(\mathrm{g} \cdot \mathrm{h})$, molar ratio of $\mathrm{O}_{2} / \mathrm{DME}$ of 0.5 and $500^{\circ} \mathrm{C}-700^{\circ} \mathrm{C}$, and this temperature range was also the operation temperature range for intermediate temperature SOFC.

For catalysts, in addition to activity and selectivity, their lifetime is also an important indicator of the performance of the catalyst. There are many factors that affect the life, and the deposition of reaction by-products, such as carbon deposition, is the main problem that leads to deactivation of catalysts and limits the industrial application of DME hydrogen production technology.

\section{Conclusion}

The commercialization of fuel cell vehicle is not only restricted by the development level of fuel cell itself, but also affected by the fuel supply facilities and fuel storage. An ideal hydrogen fuel vehicle with its high energy density, low carbon content and convenient transportation and storage and other advantages, and the hydrogen production unit size are advised, and can be made into a mobile device to satisfy the requirements of different users of hydrogen source. From the overall situation, the current study on DME reforming hydrogen production catalyst has just started, the future development of DME catalysts with high performance, to carry out research on DME catalytic reaction mechanism and reaction kinetics, the development of membrane technology, has important significance to improve the level of hydrogen storage. Hydrogen fuel is the most promising fuel cell electric vehicle. DME hydrogen mixing combustion can improve engine efficiency and reduce emissions. Therefore, in order to realize the convenient and safe hydrogen production on the vehicle, a variety of hydrogen 
production technologies must be studied, including steam reforming, partial oxidation, autothermal reforming and plasma weighting.

\section{References}

[1] Schmidt, V.M. and Brockerhoff, P. (1994) Utilization of Methanol for Polymer Electrolyte Fuel Cells in Mobile Systems. Journal of Power Sources, 49, 299-313.

[2] Barreto, L., Makihira, A. and Riahi, K. (2003) The Hydrogen Economy in the 21st Century: A Sustainable Development Scenario. International Journal of Hydrogen Energy, 28, 267-284. https://doi.org/10.1016/S0360-3199(02)00074-5

[3] Yamada, Y., Mathew, T., Ueda, A., Shioyama, H. and Kobayashi, T. (2006) A Novel DME Steam-Reforming Catalyst Designed with Fact Database On-Demand. Applied Surface Science, 252, 2593-2597. https://doi.org/10.1016/j.apsusc.2005.05.087

[4] Tsolakis, A. and Megaritis, A. (2004) Catalytic Exhaust Gas Fuel Reforming for Diesel Engines-Effects of Water Addition on Hydrogen Production and Fuel Conversion Efficiency. International Journal of Hydrogen Energy, 29, 1409-1419. https://doi.org/10.1016/j.ijhydene.2004.01.001

[5] Tsolakis, A. and Megaritis, A. (2004) Exhaust Gas Assisted Reforming of Rapeseed Methyl Ester for Reduced Exhaust Emissions of CI Engines. Biomass and Bioenergy, 27, 493-505. https://doi.org/10.1016/j.biombioe.2004.04.007

[6] Faungnawakij, K., Tanaka, Y., Shimoda, N., Fukunaga, T., Kawashima, S., Kikuchi, R. and Eguchi, K. (2007) Hydrogen Production from Dimethyl Ether Steam Reforming Overcomposite Catalysts of Copper Ferrite Spinel and Alumina. Applied Catalysis B: Environmental, 74, 144-151.

https://doi.org/10.1016/j.apcatb.2007.02.010

[7] Semelsberger, T.A., Ott, K.C., Borup, R.L. and Greene, H.L. (2006) Generating Hydrogen-Richfuel-Cell Feeds from Dimethyl Ether (DME) Using Cu/Zn Supported on Various Solid-Acid Substrates. Applied Catalysis A: General, 309, 210-223. https://doi.org/10.1016/j.apcata.2006.05.009

[8] Kawabata, T., Matsuoka, H., Shishido, T., Li, D., Tian, Y., Sano, T. and Takehira, T.


Catalyst Prepared by Homogeneous Precipitation. Applied Catalysis A: General, 308, 82-90. https://doi.org/10.1016/j.apcata.2006.04.032

[9] Nilsson, M., Pettersson, LJ. and Lindstrom, B. (2006) Hydrogen Generation from Dimethyl Ether for Fuel Cell Auxiliary Power Unites. Energy Fuel, 20, 2164-2169. https://doi.org/10.1021/ef050419g

[10] Semelsberger, T.A., Ott, K.C., Borup, R.L. and Greene, H.L. (2005) Role of Acidity on the Hydrolysis of Dimethyl Ether (DME) to Mthanol. Applied Catalysis B: Environmental, 61, 281-287. https://doi.org/10.1016/j.apcatb.2005.05.014

[11] Elewuwa, F.A. and Makkawi, Y.T. (2015) Hydrogen Production by Steam Reforming of DME in a Large Scale CFB Reactor. Part I: Computational Model and Predictions. International Journal of Hydrogen Energy, 40, 15865-15876. https://doi.org/10.1016/j.ijhydene.2015.10.050

[12] Elewuwa, F.A. and Makkawi, Y.T. (2016) A Computational Model of Hydrogen Production by Steam Reforming of Dimethyl Ether in a Large Scale CFB Reactor. Part II: Parametric Analysis. International Journal of Hydrogen Energy, 41, 19819-19828. https://doi.org/10.1016/j.ijhydene.2016.08.072

[13] Feng, D.M., Wang, Y., Wang, D. and Wang, J. (2009) Steam Reforming of Dimethyl Ether over CuO-ZnO- $\mathrm{Al}_{2} \mathrm{O}_{3}-\mathrm{ZrO}_{2}+\mathrm{ZSM}-5$ : A Kinetic Study. Chemical Engineering Journal, 146, 477-485. https://doi.org/10.1016/j.cej.2008.11.005 
[14] Creaser, D., Nilsson, M., Pettersson, LJ. And Dawody, J. (2010) Kinetic Modeling of Autothermal Reforming of Dimethyl Ether. Industrial and Engineering Chemistry Research, 49, 9712-9719. https://doi.org/10.1021/ie100834v

[15] Akbari, M.H., Ardakani, A.H.S. and Tadbir, M.A. (2011) A Microreactor Modeling, Analysis and Optimization for Methane Autothermal Reforming in Fuel Cell Applications. Chemical Engineering Journal, 166, 1116-1125.

https://doi.org/10.1016/j.cej.2010.12.044

[16] Matsumoto, T., Nishiguchi, T., Kanai, H., Utani, K., Matsumura, Y. and Imamura, S. (2004) Steam Reforming of Dimethylether over H-Moedenite-Cu/CeO 2 Catalysts. Applied Catalysis A: General, 276, 267-273. https://doi.org/10.1016/j.apcata.2004.08.013

[17] Takeishi, K. and Suzuki, H. (2004) Steam Reforming of Dimethyl Ether. AppliedCatalysis A: General, 260, 111-117. https://doi.org/10.1016/j.apcata.2003.10.006

[18] Suh, J.S., Lee, M.T., Greif, R. and Grigoropoulos, C.P. (2007) A Study of Steam Methanol Reforming in a Microreactor. Journal of Power Sources, 173, 458-466. https://doi.org/10.1016/j.jpowsour.2007.04.038

[19] Chein, R., Chen, Y.C. and Chung, J.N. (2013) Numerical Study of Methanol-Steam Reforming and Methanol-Air Catalytic Combustion in Annulus Reactors for Hydrogen Production. Applied Energy, 102, 1022-1034. https://doi.org/10.1016/j.apenergy.2012.06.010

[20] Galvita, VV., Semin, GL., Belyaev, VD., Yurieva, TM. and Sobyanin, V.A. (2001) Production of Hydrogen from Dimethyl Ether. Applied Catalysis A: General, 216, 85-90. https://doi.org/10.1016/S0926-860X(01)00540-3

[21] Nilsson, M., Jansson, K., Jozsa, P. and Pettersson, L.J. (2009) Catalyst Properties of Pd Supported on $\mathrm{ZnO} / \mathrm{ZnAl}_{2} \mathrm{O}_{4} / \mathrm{Al}_{2} \mathrm{O}_{3}$ Mixtures in Dimethyl Ether Autothermal Reforming. Applied Catalysis B: Environmental, 86, 18-26. https://doi.org/10.1016/j.apcatb.2008.07.012

[22] Zhang, Q., Li, X., Fujimoto, K. and Asami, K. (2005) Hydrogen Production by Partial Oxidation and Reforming of DME. Catalysis Letters, 102, 197-200. https://doi.org/10.1007/s10562-005-5855-5

[23] Chen, Y., Shao, Z. and Xu, N. (2008) Partial Oxidation of Dimethyl Ether to H/Syngas over Supported Pt Catalyst. Journal of Natural Gas Chemistry, 17, 75-80. https://doi.org/10.1016/S1003-9953(08)60029-8 